Original Research Paper

\title{
Jumping Spider (Arachnida: Salticidae: Araneae) in Serang Residential Area, Banten: Inventory Study Using A Photographic Approach
}

\author{
Riski Andrian Jasmi ${ }^{1 *}$, Herlina Putri Endah Sari ${ }^{2}$, Muhammad Nazri Janra ${ }^{3}$ \\ ${ }^{1}$ Department of Biology, Faculty of Science, UIN Sultan Maulana Hasanuddin Banten, Indonesia; \\ ${ }^{2}$ Department of Biology, Faculty of Engineering, Universitas Samudra, Indonesia; \\ ${ }^{3}$ Department of Biology, Faculty of Mathematics and Natural Science, Universitas Andalas, Indonesia
}

\author{
Article History \\ Received : October $24^{\text {th }}, 2021$ \\ Revised : December 07 $7^{\text {th }}, 2021$ \\ Accepted : December $20^{\text {th }}, 2021$ \\ Published : January $05^{\text {th }}, 2022$ \\ *Corresponding Author: \\ Riski Andrian Jasmi, \\ UIN Sultan Maulana Hasanuddin, \\ Banten, Indonesia; \\ Email: \\ riski.andrian@uinbanten.ac.id
}

\begin{abstract}
Ecosystem changes due to human activities can affect habitats for several organisms, such as spiders. Spiders have an important role as a predator for mosquitoes, flies, and ants. One of the spider families is Salticidae. Most species from Salticidae are cosmopolitan and often found in an area with dense human activity, such as residential areas. Study about spider species in residential areas is important to determine the effect of urbanization on spider diversity. This research aimed to study about spider species from Salticidae family found in the Serang Residential Area. The individual spider was caught directly by hand, then documented with macro photography techniques. Data analysis was carried out by describing the morphological characters. The results showed 5 species, namely Hasarius adansoni, Menemerus nigli, Menemerus fulvulus, Plexippus paykulli and Plexippus petersi. Documentation using good photography helps in making identification easier. This research is expected to be used as a reference for further research about a spider in a residential area.
\end{abstract}

Keywords: Salticidae, Hasarius adansoni, Menemerus nigli, Plexippus paykulli

\section{Introductiom}

Land conversion causes ecosystem changes that can reduce the size and number of natural habitats. On the other side, human activities can create new microhabitats, such as residential, agriculture, parks, and industrial areas. Spiders (Subphylum Arthropoda, Class Arachnida) are organisms that can be found in almost all types of ecological environments (Foelix, 2011). Spiders adapt to new microhabitats created by humans such as residential areas (Argañaraz and Gleiser, 2021).

One of the cosmopolitan spider families found in residential areas is Salticidae or Jumping Spider (Zabka \& Gardzinska, 2017; Zabka \& Nentwig, 2000). Several species of jumping spiders have broad ecological requirements, so they can be found almost all over the world. The high dispersal ability to jump spiders depends on size, life strategy, habitat, and climatic conditions such as wind, but the exact dispersal mechanism is unknown (Zabka \& Nentwig, 2000). Spiders from the Salticidae family are important organisms because they act as predators that control pest populations in a residential area such as mosquitoes, flies, and ants (Wetering \& Umponstira, 2014; Richman \& Jackson, 1992). Salticidae spiders are diurnal spiders that do not use webs to catch prey, but instead ambush directly by relying on well-developed eyesight (Foelix, 2011; Jocque \& Dippenaar-Schoeman, 2007; Richman \& Jackson, 1992). The family Salticidae is Suborder Araneomorphoe or Labidognatha which is characterized by the position of the chelicerae in opposite directions from each other. Salticidae has a small size, the body is covered by hairs, short legs, a large cephalothorax that is square and is easily distinguished from other families based on 4 pairs of eyes that are lined up with 4 large anterior eyes and straight forward (Foelix, 
2011; Jocque \& Dippenaar-Schoeman, 2007; Richman \& Jackson, 1992). It is estimated that 550 genera are consisting of 5,000 described species of Salticidae scattered throughout the world (Zabka \& Gardzinska, 2017; Zabka \& Nentwig, 2000), with an estimated 500 species found in Indonesia (WSC, 2021).

Study about spider species in residential areas is important to determine the effect of urbanization on spider diversity. Research on spiders in residential has been carried out in Western Tripura, India (Dey et al., 2013), in Guerrero Mexico (Rodriguez-Rodriguez et al., 2015), and Belgium (Jocque et al., 2016), but research on spiders from residential areas in Indonesia are still rare and have not been published yet. In addition, the identification of spiders in residential is also important in terms of taxonomy, diversity, and conservation. This study aimed to determine the species of Salticidae spider found in the Serang Banten Residential Area with a photographic approach. Documentation using photography has the advantage that the specimen looks very clear and sharp, it is easy to see morphological characteristics, and does not have to collect spider species directly for identification purposes. In addition, the use of macro photography for the identification of Salticidae spiders is simpler without the use of laboratory equipment, making identification easier.

\section{Materials and Methode}

\section{Site and Time}

This study used a field survey method located in Citra Gading Housing, Cipocok Jaya District, Serang City, Banten (6008'53.0"S; 106O10'07.1"E) (Figure 1) which was conducted from October 28, 2018, to March 9, 2020.

\section{Data collection}

The individual spider was caught directly by hand and then killed with chloroform to reduce movement so that the photos obtained are sharp. Immediately the specimen was documented with macro photography techniques using a Canon 70 D camera, Canon Macro 100 mm 2.8 lenses, raynox DCR 250, and lighting using an LED lamp with an artificial light diffuser to produce soft lighting. Photos were processed with focus staking techniques using
Helicon Focus software version 6.0.18.0 to produce a wide focus.

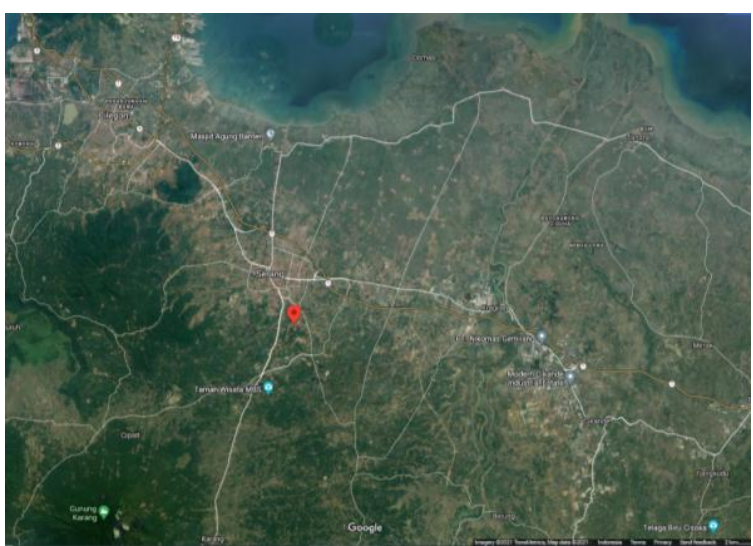

Picture 1. Location of the Salticidae collection in Citra Gading Housing, Serang City Banten (Source: Google Earth 2020).

\section{Data Analysis}

The spider was photographed from the front, lateral, ventral and dorsal side to show complete morphological characters, especially the color, pattern, presence and hair color on the exoskeleton, cephalothorax, pars cephalic, pars thoracic, abdomen, sternum, legs, eyes, eye field, chelicera, clypeus, and palpus. Photographs of spiders and their documented characteristics were then identified using guidelines for the family Salticidae (Zabka, 1985; Zabka and Gardzinska, 2017).

\section{Results}

Based on research, the result showed that there are 5 species of Salticidae, namely Hasarius adansoni, Menemerus bivittatus, Menemerus nigli, Plexippus paykulli and Plexippus petersi.

\section{a. Hasarius adansoni (Audouin, 1826)}

Males and females have different colors, shapes and sizes. The male exoskeleton (Figure 2) is light brown and is covered with black hair. The cephalothorax is almost rounded with the same length and width. There is a white line forming a semicircle on the thoracic and dorsal margins of the base of the abdomen. There are four white dots on the dorsal posterior abdomen, two points larger than the two on the tip of the abdomen (Fig. 2.a). The ventral part has a darker color on the anterior than the posterior part. The ventral parts 
of the legs and abdomen have white hair (Fig. 2.b). On the legs there are black and white hairs, the first leg is darker than the other leg (Figure 2.c). The eyes are black, surrounded by orange hair on the sides and top, and white on the bottom. Chelicera and clypeus are dark blacks in color. The palps are covered with black hair and on the dorsal side, they are covered with white hair (Fig. 2.d).

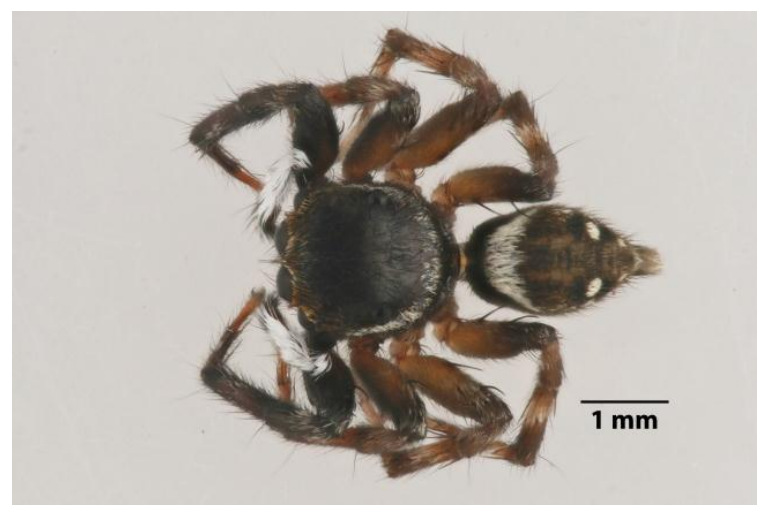

a

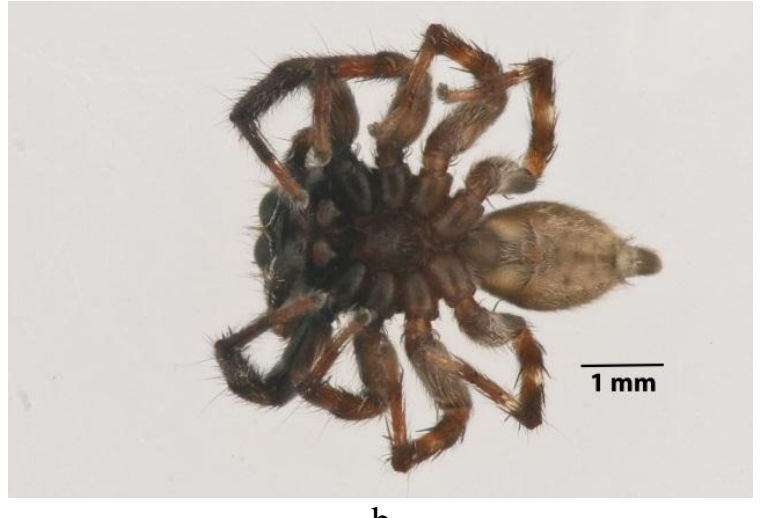

b

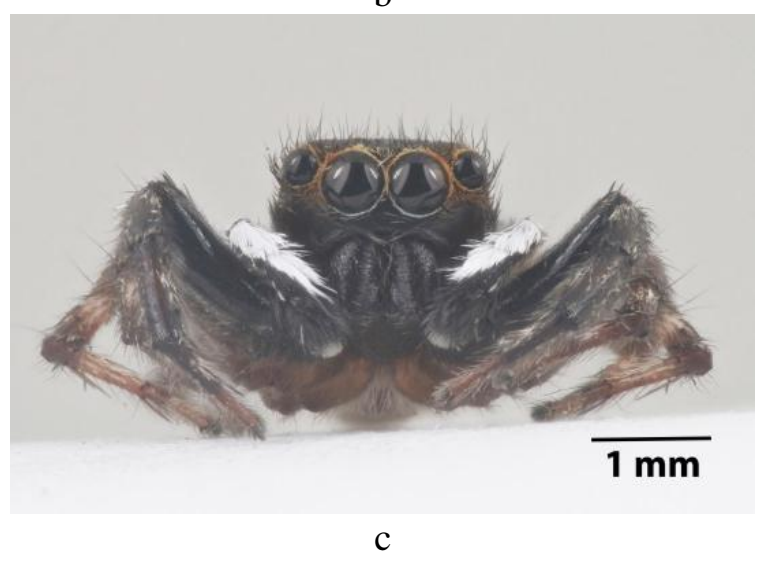

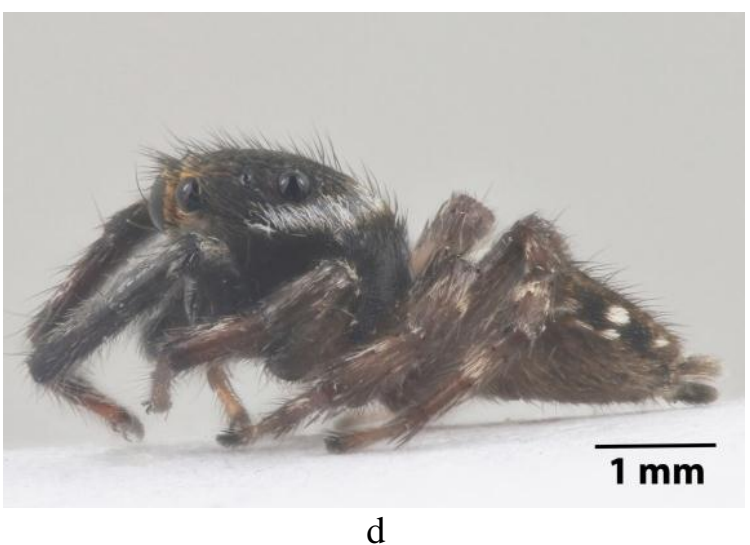

Picture 2. Hasarius adansoni, male: (a) dorsal side; (b) ventral side; (c) frontal side; (d) lateral side

The female exoskeleton (Figure 3) is light brown and is covered with brown hair. The cephalothorax looks more elongated than the male cephalothorax, there is evenly distributed cream hair. The cephalic part is covered with black hair and the anterior part of the thoracic part is covered with yellow and reddish-brown hairs while the posterior part is not covered with hair. The base of the abdomen is covered by dark brown and covered by lighter hairs forming two transverse lines at the base of the abdomen, most of the abdomen is covered by brown hair and form a pattern (Figure 3.a). The ventral abdomen is reddish-brown in color and there are some dark brown patches (Fig. 3.b). All legs are brown covered by brown and cream hairs (Figure 3.c). Black eyes surrounded by yellow hair. The eye field is covered with yellow and black hairs. Chelicera is dark brown to reddish and the clypeus is covered by yellow hair. The palps are covered by yellow hair (Fig. 3.d).

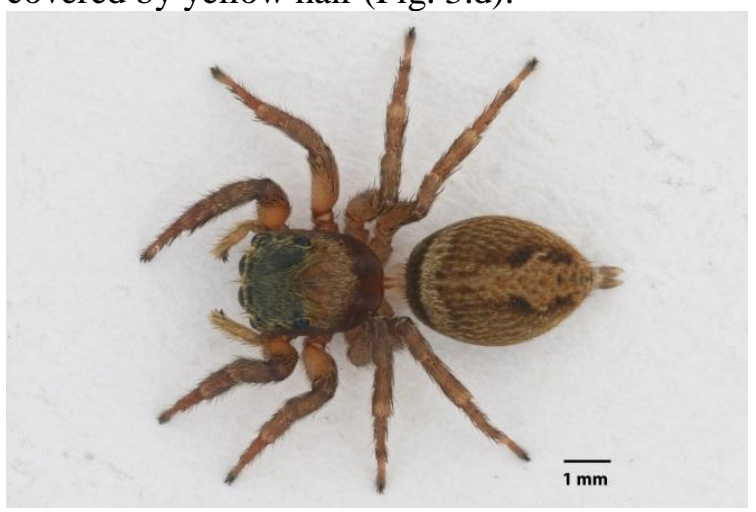

a 

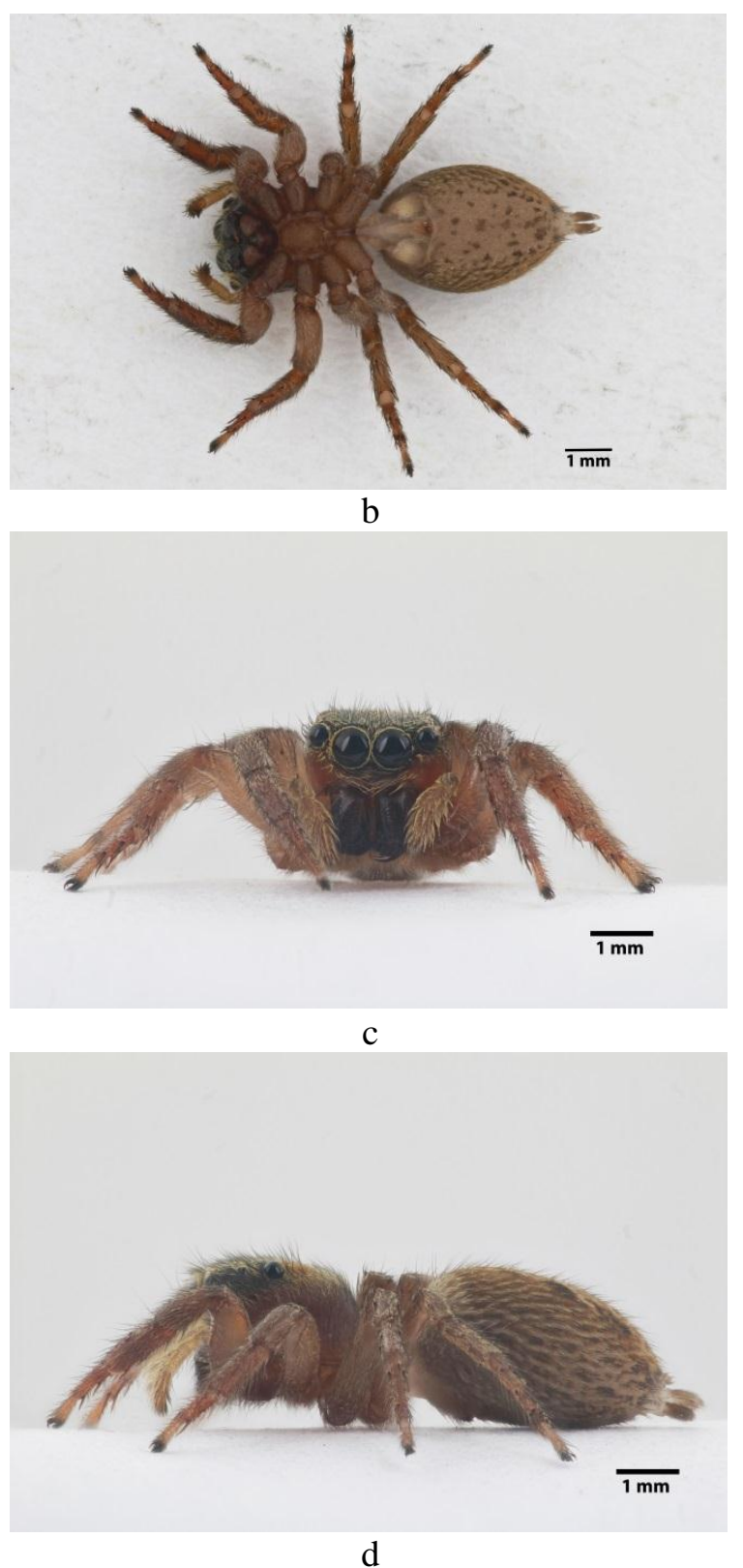

Picture 3. Hasarius adansoni, female: (a) dorsal side; (b) ventral side; (c) frontal side; (d) lateral side

\section{b. Menemerus bivittatus (Dufour, 1831)}

Males and females have different colors, shapes and sizes. The male exoskeleton (Figure 4) is black and reddish-brown. The cephalothorax is larger than the abdomen. The dorsal part of the cephalothorax is covered by black hair, there are white hairs that are clustered in the middle and there are some scattered red hairs. On the lateral side of the cephalothorax, there is a white line from the clypeus to the posterior pars thoracica. There is a thick black longitudinal line in the middle of the dorsal abdomen from the base to the tip of the abdomen. There is a thick white longitudinal line next to the black line (Figure 4.a). The ventral abdomen is light brown and has black hair on the middle and white hair on the lateral side. Around the sternum are white hairs (Fig. 4.b). On the lateral side of the abdomen, there is a black line running from the base to the tip of the abdomen. The black legs are covered by white, black, and reddish-brown hairs. The forelegs are darker than the hind legs (Figure 4.c). The dorsal palps are also covered with white hair. The eyes are black surrounded by red hair forming a band on the eye. The chelicera is dark black and the clypeus is covered with white hair (Figure 4.d).
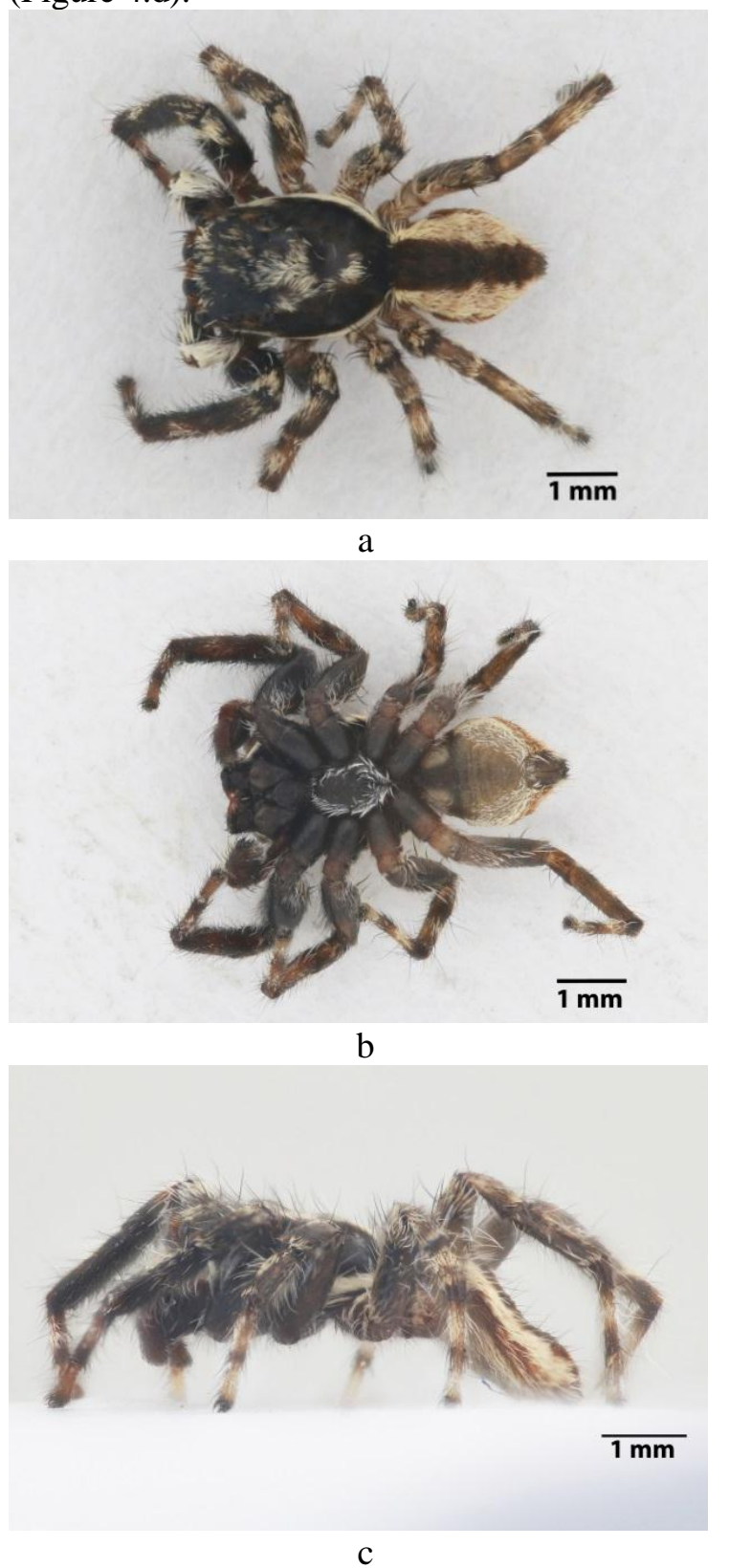


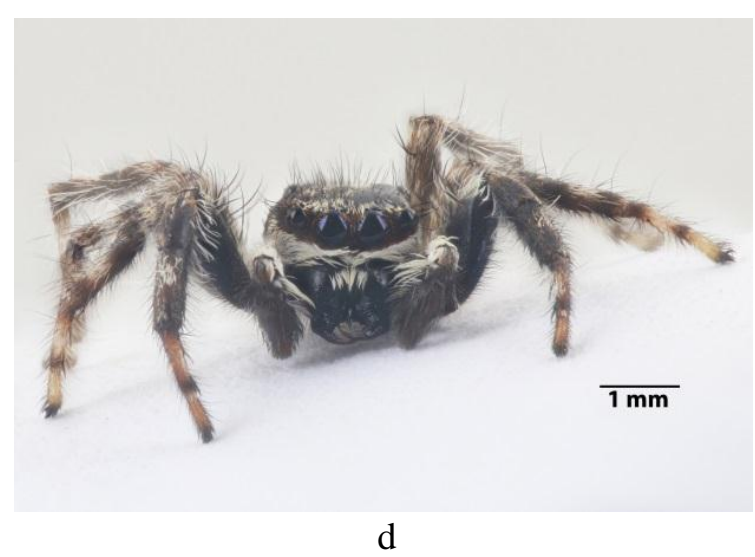

Picture 5. Menemerus bivittatus, female: (a) dorsal side; (b) ventral side; (c) lateral side; (d) frontal side

The female exoskeleton color (Figure 5) is cream. The size of the cephalothorax is almost the same as the size of the abdomen. The dorsal cephalothorax is covered with black hair, there is a lot of cream hair in the middle and also some scattered reddish-brown hairs. On the lateral side of the cephalothorax, there is a line that resembles a white band. The dorsal abdomen is covered with white hair and there are some black hairs forming patches. There is a thick black longitudinal line on the lateral side of the abdomen from the base to the tip of the abdomen (Fig. 5.a). The ventral cephalothorax is dark in color and the sternum is surrounded by white hair. The ventral abdomen is white and covered by white hair (Fig. 5.b). The exoskeleton of the legs is cream-brown and is covered with white hair (Fig. 5.c). The palps are covered by white hairs. The eyes are black, surrounded by reddish-brown hair that forms a band in the eye field. The chelicera are dark black and the clypeus is covered with red hair (Fig. 5.d).

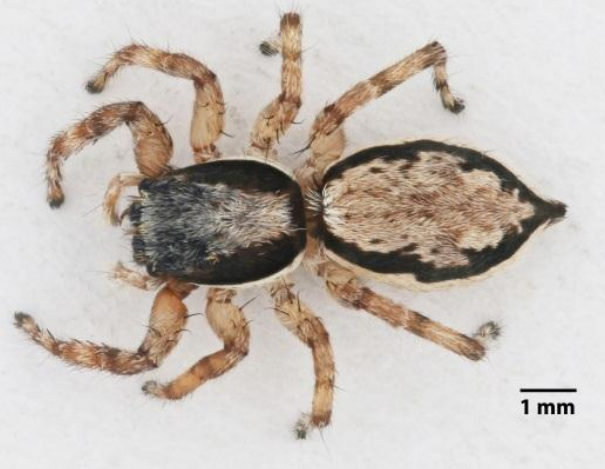

a

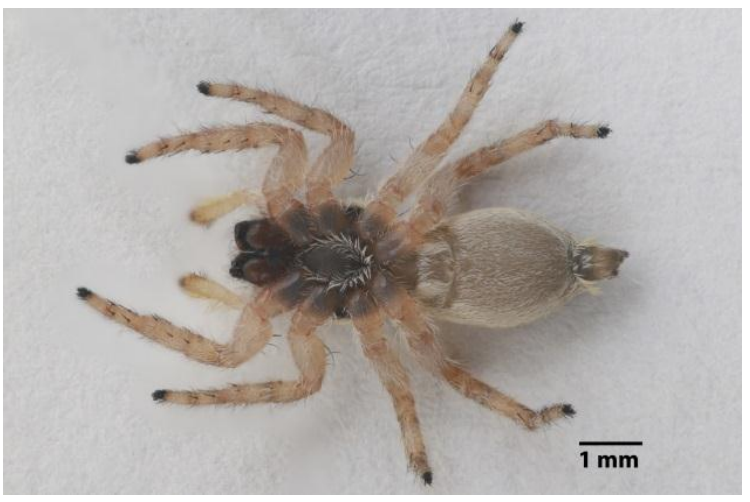

b
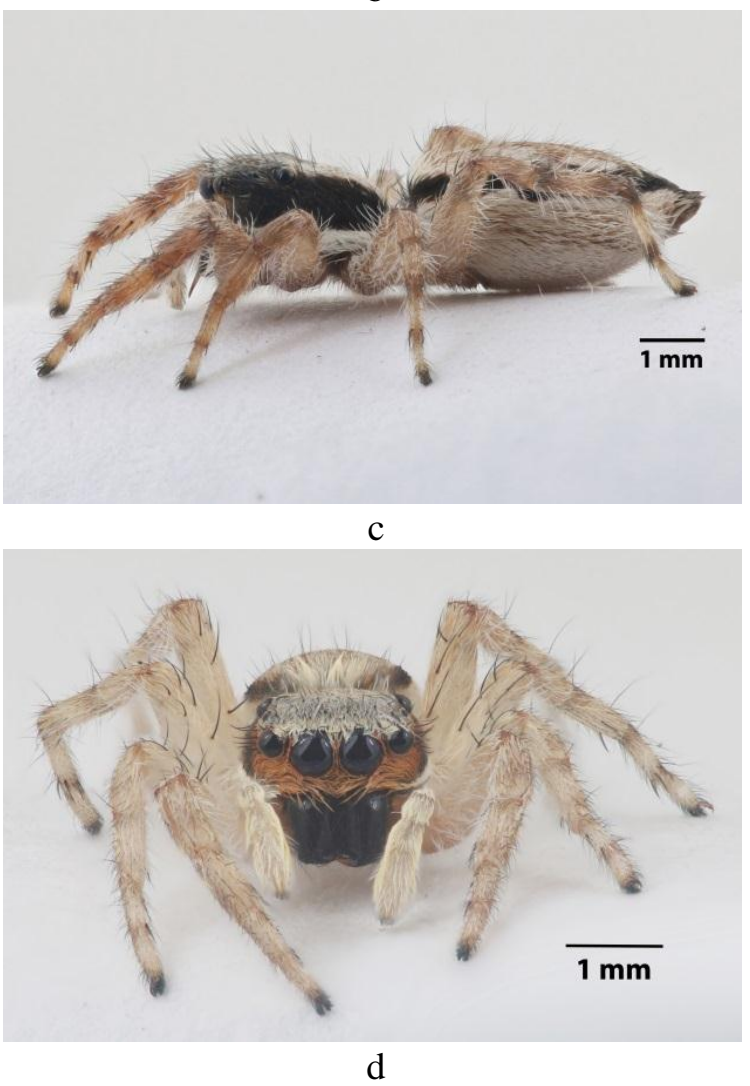

Picture 5. Menemerus bivittatus, female: (a) dorsal side; (b) ventral side; (c) lateral side; (d) frontal side

\section{c. Menemerus nigli (Wesolowska \& Freudenschuss 2012)}

The Menemerus nigli that were obtained in the research were female individuals. The female (Figure 6) is a mixture of dark brown, light brown and white. The cephalothorax is smaller than the abdomen. The dorsal cephalothorax is covered by dark brown hair, there are many white hairs scattered in the middle in a pattern and also some scattered red hairs. On the lateral side of the cephalothorax, there is a line that resembles a white band from the clypeus to the posterior part 
of the thoracic. The dorsal abdomen is covered by brown hair and white hairs are forming a pattern (Fig. 6.a). The ventral cephalothorax is dark in color and the sternum is surrounded by white hair. The ventral abdomen is dark in color and covered by white hair (Fig. 6.b). The exoskeleton of the legs is yellowish-brown and covered with white hair (Fig. 6.c). The brownish-white palps are covered with white hairs. Black eyes surrounded by red hair form a ribbon in the eye field. The chelicera is dark black and the clypeus is covered with white hair (Fig. 6.d). These characteristics are following the description of Ali et al (2018).

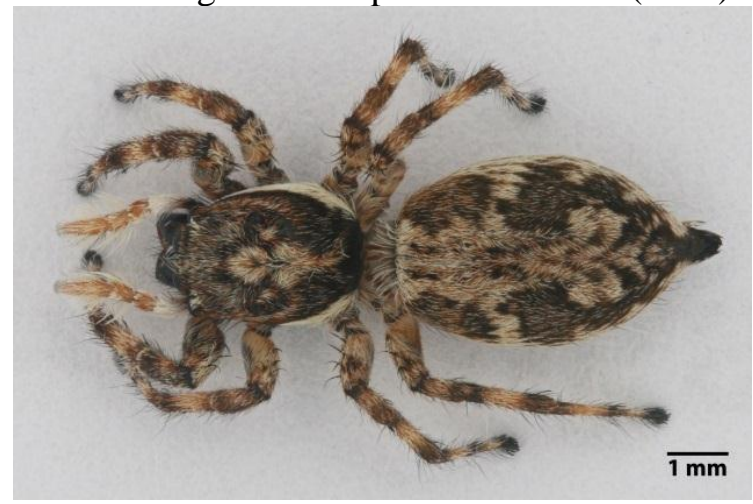

a

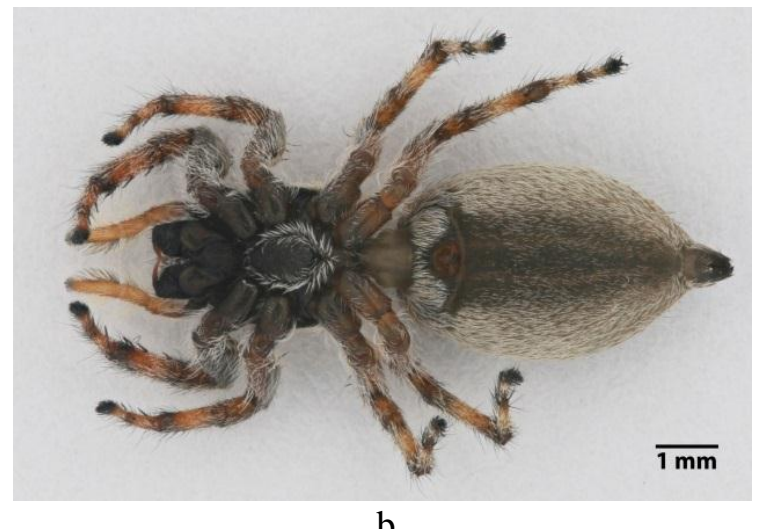

b

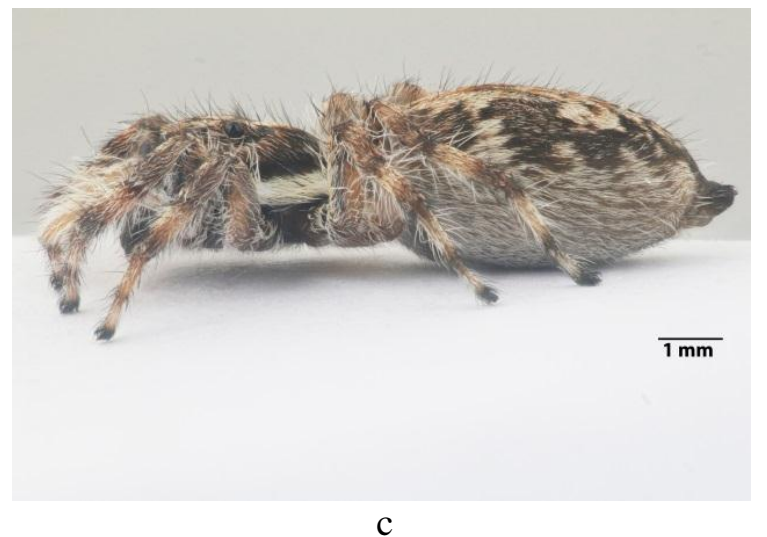

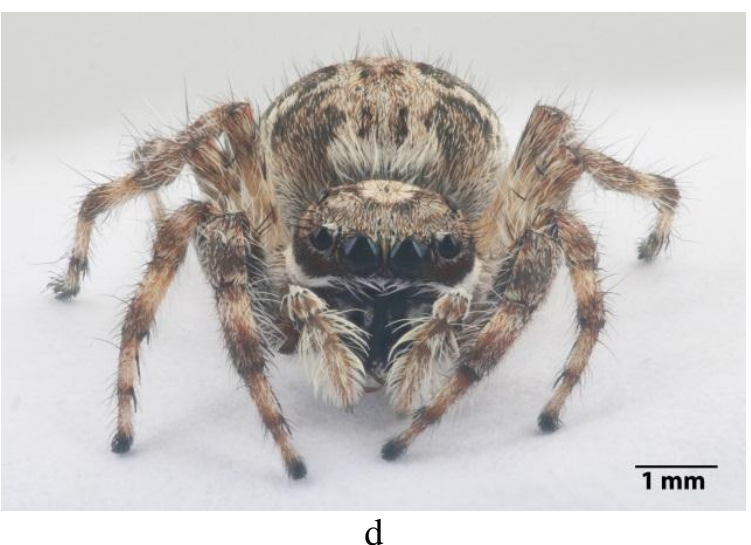

Picture 6. Menemerus nigli, female: (a) dorsal side; (b) ventral side; (c) lateral side; (d) frontal side

\section{d. Plexippus paykulli (Adounin, 1826)}

Males and females have different colors, shapes and sizes. The male exoskeleton (Figure 7) is light brown. The size of the cephalothorax is larger than the size of the abdomen. The dorsal part of the cephalothorax is covered by black hair and there is white hair that forms a thick line from the anterior center of the median eye to the posterior cephalothorax. On the lateral side, there are white hairs that form a longitudinal line from below the anterior lateral eye to the posterior cephalothorax. The dorsal part of the abdomen is covered by black hair but some hairs form a thick white line that longitudinally from the base to the posterior end of the abdomen. On the posterior abdomen, there is a box-like pattern that rarely grows hair and there are also four white dots (Fig. 7.a). There are four dark areas on the anterior ventral abdomen and one dark spot on the posterior abdomen and there are some white hairs scattered all over the ventral abdomen. There are yellow hairs on the sternum (Fig. 7.b). The exoskeleton of the legs is light brown and is covered with yellow, white and black hairs (Figure 7.c). Chelicerae are black. The anterior median eye is green. There are reddish-yellow hairs that form a vertical line under the anterior median eye, between the anterior eyes there are hairs that form a white vertical line. The palps are dominated by brownish-yellow hairs and white hairs are forming a circle on the palpate tegulum. Clypeus is covered by white hairs (Fig. 7.d). 


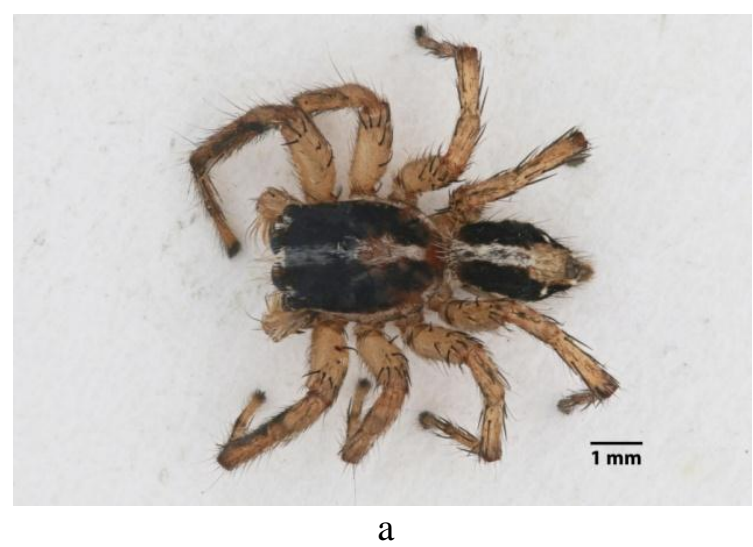

a

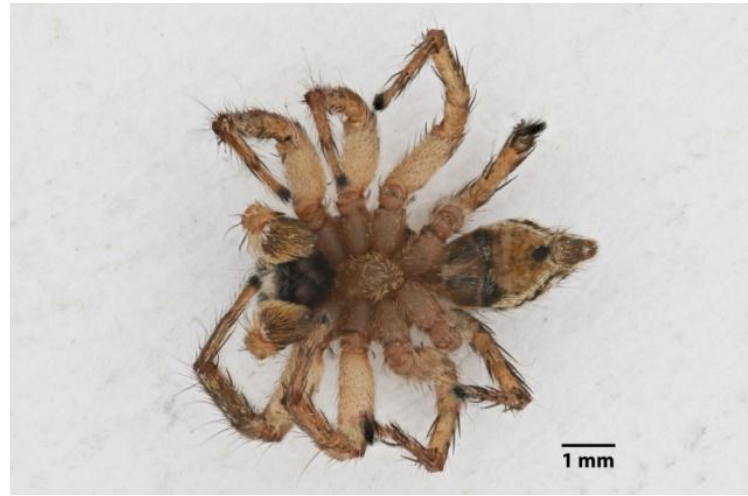

b
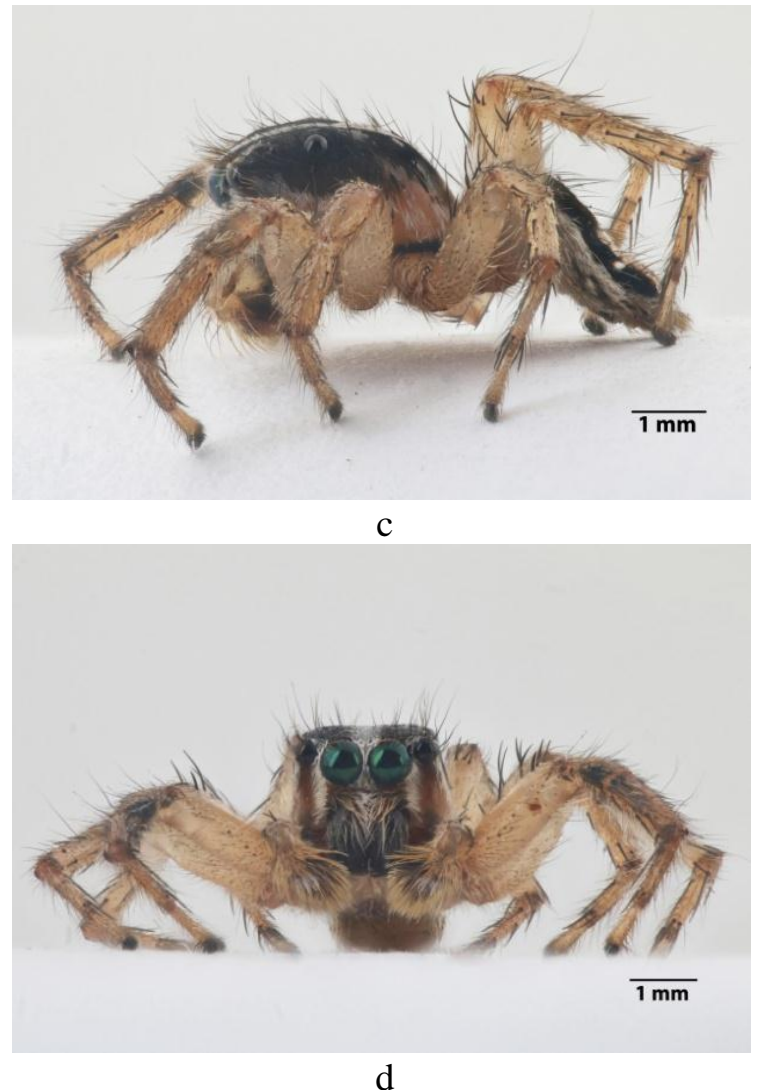

Picture 7. Plexippus paykulli, male: (a) dorsal side; (b) ventral side; (c) lateral side; (d) frontal side
The female exoskeleton is brown and covered by brown, whitish brown, white and black hairs (Figure 8). The cephalothorax is dominated by brown hairs, there is a bright line in the middle of the pars thoracica. The size of the cephalothorax is smaller than the size of the abdomen. The abdomen is dominated by brown hairs and there is a bright line in the middle and lateral sections that extend from the base of the abdomen to the tip of the abdomen. There are two large brownish white dots on the dorsal abdomen and two small white dots on the posterior side (Fig. 8.a). The ventral cephalothorax is brown and there is yellow hair on the sternum. The ventral part of the abdomen is light brown with scattered black spots, there is also a dark longitudinal line in the middle of the abdomen from the epigastric fold to the tracheal spiracle (Fig. 8.b). The legs are dark brown and there are evenly distributed white and light brown hairs (Figure 8.c). The palps are covered by yellowish-white hairs. The anterior median eye is greenish-black and is surrounded by reddish-brown hairs forming a band covering the eye field. Chelicera and clypeus are dark brown and covered with white hairs (Fig. 8.d).

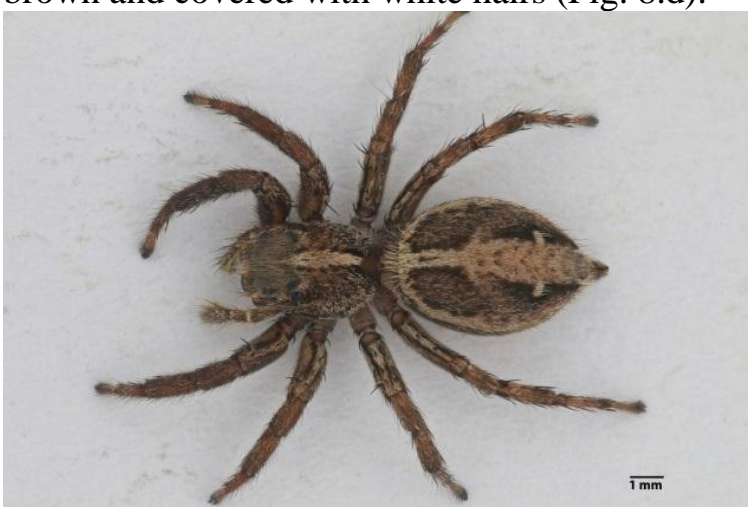

a

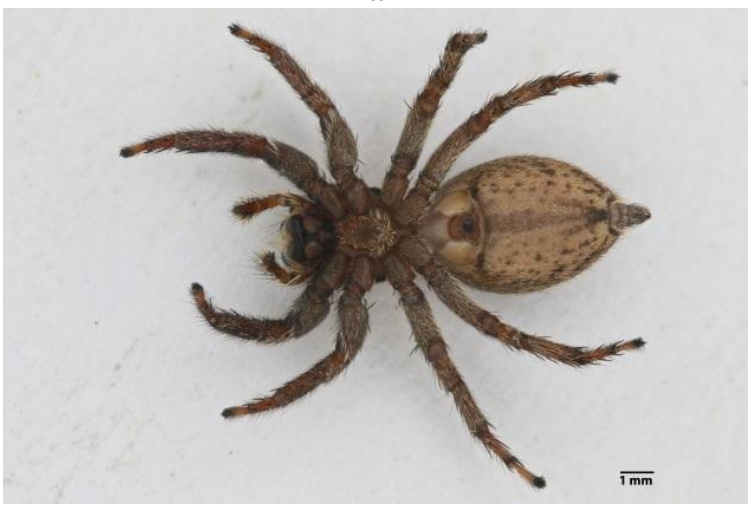

b 

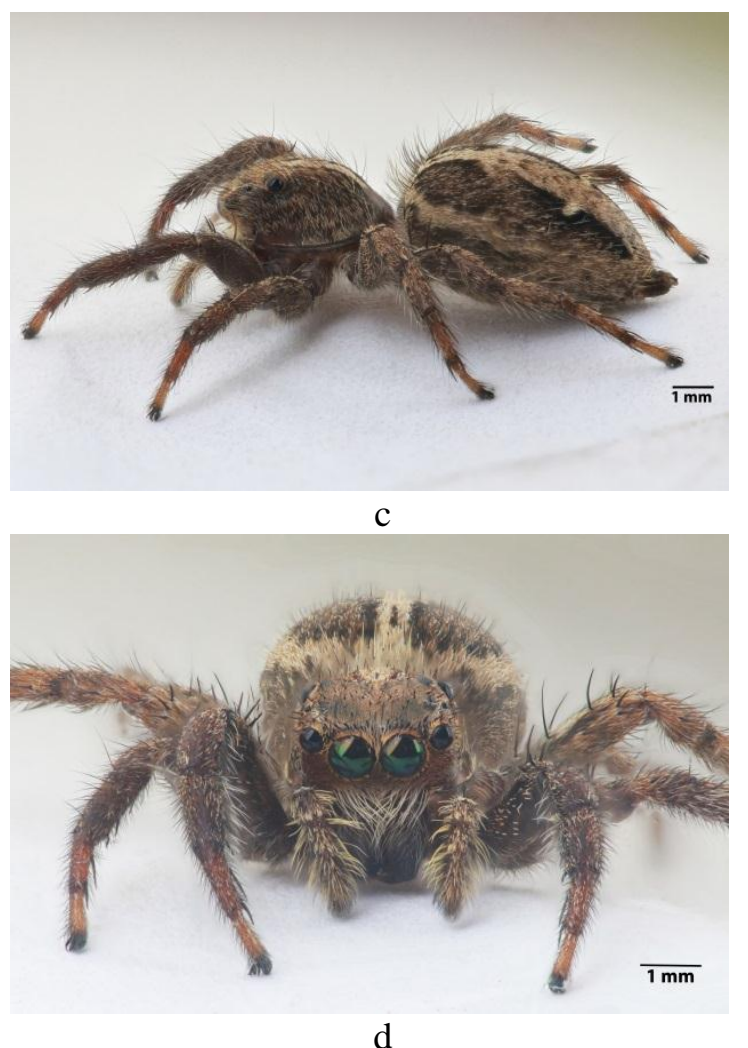

Picture 8. Plexippus paykulli, female: (a) dorsal side; (b) ventral side; (c) lateral side; (d) frontal side

\section{e. Plexippus petersi (Karsch, 1878)}

In male individuals (Figure 9) dominated by white and black hair. The size of the cephalothorax is larger than the size of the abdomen. Dorsal pars cephalic is dominated by black hair, brownish-yellow and white hair. The dorsal pars thoracica is covered with white hair and there are black hairs that form two large black stripes on the right and left sides of the dorsal. The dorsal abdomen is also covered with white hairs and are forming two large black stripes on the right and left sides of the dorsal, there are also two white spots on the posterior abdomen (Fig. 9.a). The ventral part of the abdomen is covered with black hair on the venter and the lateral part is covered with white hair. The ventral cephalothorax contains yellow hairs (Fig. 9.b). The legs are covered by white and black hairs that form a longitudinal line (Fig. 9.c). The palps are covered by black, white and yellow hair. The eyes are greenish-black surrounded by white hair covering the anterior eye. The black and white line on the face below the anterior lateral eye is narrower than that of $\mathrm{P}$. paykulli. The chelicera is black and the clypeus are covered with yellowishwhite hairs (Fig. 9.d).

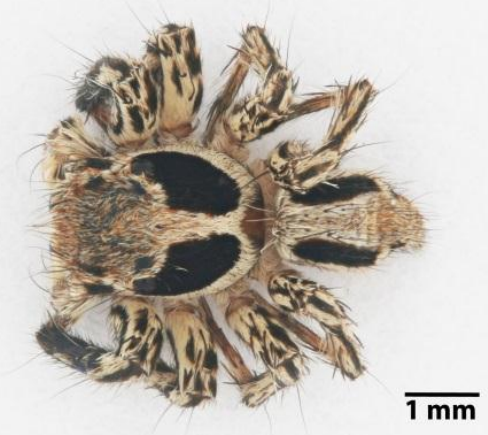

a

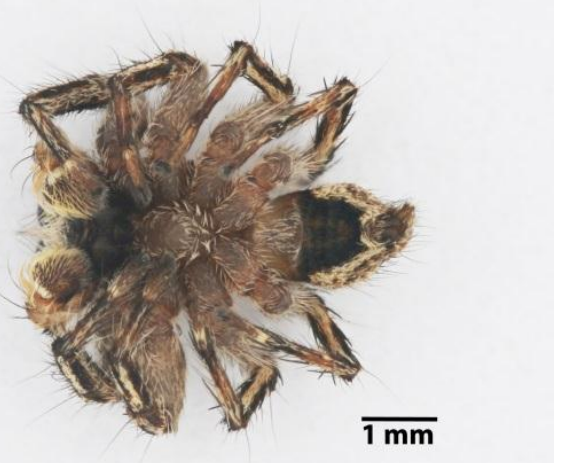

b

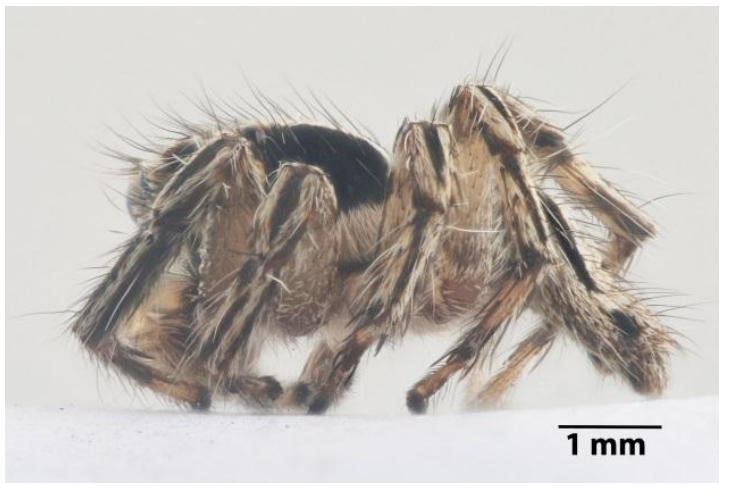

$\mathrm{c}$

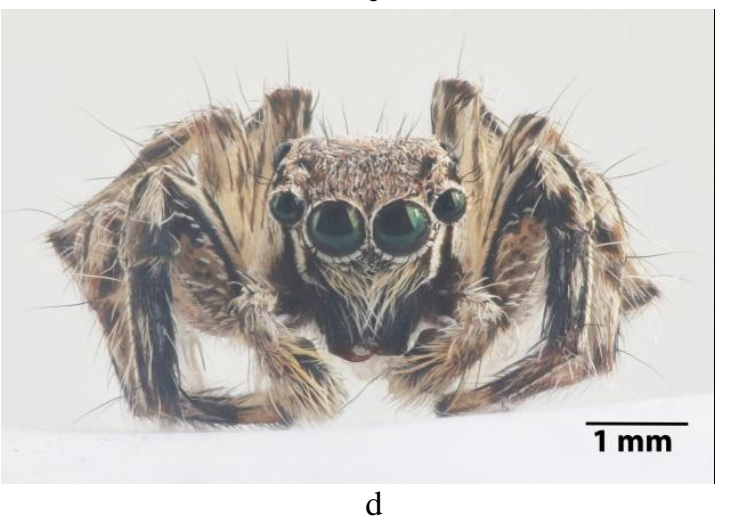

Picture 9. Plexippus petersi, male: (a) dorsal side; (b) ventral side; (c) lateral side; (d) frontal side 


\section{Discussion}

Studies about spider diversities are still rare in Indonesia, so that the literature we found is limited. Five species have been identified namely Hasarius adansoni, Menemerus bivittatus, Menemerus nigli, Plexippus paykulli, and Plexippus petersi found in settlements either indoors or outdoors, on walls, on furniture, fences, or behind rocks. Humans are not bothered by the presence of salticidae because in addition to not being aggressive and not hurting humans, salticidae also do not make nests that can make the house dirty. This habitat is very suitable for salticidae where they get protection and eat small insects that are in settlements, this ecological niche is very suitable to be filled by salticidae.

Hasarius adansoni found at the research site is following the results of various studies outside Indonesia. Hasarius adansoni exhibits sexual dysmorphism and complex courtship behavior (Castilho Andrade, and Macedo, 2018). It is cosmopolitan and is often found in homes or human settlements. This species is found in all areas, whether rural, suburban, settlements with gardens or settlements without gardens (Rodriguez-Rodriguez et al, 2015). This species has also been found in the volcanic islands of the Sunda Strait, namely Mount Krakatau (Zabka and Nentwig, 2000). Widespread in Africa and the Middle East, then introduced to America, Europe, India, Southeast Asia, China, Japan, Australia and the Pacific (WSC, 2021; Hill, 2010; Dzulhelmi et al., 2014; Zabka \& Gardzinska, 2017) .

Menemerus bivittatus is not only a predator by capturing live prey but is also a kleptoparasite by stealing food carried by ants (Huston, 2017). Commonly found in settlements (Weterings and Umponstira, 2014) both at home and in parks (Dey et al., 2013), on riverbanks (Dzulhelmi et al., 2014) and has been found on Mount Krakatau and is a cosmopolitan species (Zabka and Nentwig, 2000). Widespread in Africa, then introduced to America, Southern Europe, China, Japan, Australia and the Pacific (WSC, 2021; Hill, 2010). Menemerus nigli is widely distributed in South Asia, Southeast Asia (WSC, 2021) and Brazil (Mariante and Hill. 2020). Menemerus nigli is often found on rocks or walls of houses (Chatterjee et al. 2017; Seyfulina et al. 2020).
Plexippus paykuli is commonly found in settlements (Weterings and Umponstira, 2014) both at home and in parks (Dey, Debbarma and Chaudhuri, 2013), in rural and urban areas (Rodriguez-Rodriguez, 2015). This species is also found in rice fields to mangrove forests (Dzulhelmi, 2014), and has been found on Mount Krakatau (Zabka and Nentwig, 2000). Widespread in Africa and introduced to America, Europe, the Middle East, Asia, Papua New Guinea, and Australia (WSC, 2021; Hill, 2010). Plexippus petersi is commonly found in settlements (Weterings and Umponstira, 2014) both at home and in parks (Dey, Debbarma and Chaudhuri, 2013). Widespread in Asia (WSC, 2021).

\section{Conclusions}

The jumping spider found in Citra Gading Housing, Cipocok Jaya District, Serang City, Banten consisted of 5 species, namely Hasarius adansoni, Menemerus nigli, Menemerus fulvulus, Plexippus paykulli and Plexippus petersi. The five species are cosmopolitan species that are spread in almost all types of ecology. There is dimorphism between male and female individuals. Documentation using good photography helps in making identification easier.

\section{References}

Ali, P. A., W. P. Maddison, M. Zahid and A. Butt (2018). New chrysilline and aelurilline jumping spiders from Pakistan (Araneae, Salticidae). ZooKeys, 783: 1-15.

Argañaraz, C. I and R. M. Gleiser (2021). Are spider communities influenced by urbanisation? An approach using species and guilds resolutions and their interaction with the anthropogenic environment. Journal of Natural History, 54, (41-42), 2687-2702. https://doi.org/10.1080/00222933.2020.1 $\underline{863496}$

Castilho, L. B., M. C.B. Andrade, and R. H. Macedo (2018). Mating and egg-laying behavior of Hasarius adansoni (Araneae: Salticidae) and the influence of sexual 
selection. Journal of Arachnology, 46:398-403.

Chatterjee, S., J. T. D. Caleb, K. Tyagi, S. Kundu and V. Kumar, V. (2017). First report of Menemerus nigli (Araneae: Salticidae) from India. Halteres, 8: 109-111.

Dey, A., S. Debnath, B. Debbarma, and P. S. Chaudhuri (2013). A Preliminary Study on Spider Diversity from A House Hold Garden (Artificial Mixed Plantation) in West Tripura, India. Journal of Research in Biology, 3 (5), 1009-1017.

Dzulhelmi, M.M., Wong, C.X., Goh, T.G., Juhaida, H., \& Faszly, R. (2014). Spider fauna (Arachnida, Araneae) from Sabah, Malaysia. Journal of Entomolgy and Zoology, 2 (5): 335-344.

Foelix, R.F. (2011). Biology of Spider. UK: Oxford University Press.

Hill, D. H. (2010). Sunda to Sahul: TransWallacean distribution of recent salticid genera (Araneae: Salticidae). Peckhamia $80.1,1-60$

Huston, D.C. (2017). Train robbery: Menemerus bivittatus (Dufour, 1831) (Araneae: Salticidae) steals larvae of Technomyrmex sophiae Forel, 1902 (Hymenoptera: Formicidae) in transit. Australian Entomologist. 44 (2), 85-88.

Jocque, R., Baert, L., De Smedt, P., Bosselaers, J., Souffreau, J.,Henrard, A., Janssen, M., Alderweireldt, M., Oger, P., Bosmans, R., Fannes, W., Jansen, L., Decae, A., \& Sleeuwaert, T. (2016). An introductury study of house spiders (Araneaae) in Belgium. Arachnology. 17 (3), 129-136

Jocque, R. \& A.S. Dippenaar-Schoeman (2007). Spider families of the world. Royal Museum for Central Africa. Tervuren

Mariante, R. M. and D. E. Hill (2020). First report of the Asian jumping spider Menemerus nigli (Araneae: Salticidae: Chrysillini) in Brazil. Peckhamia 205.1. 1-
21

Richman, D.B. \& Jackson, R.R. (1992). A review of the ethology of jumping spider (Araneae, Salticidae). Bull. Br. arachnol. Soc., 9 (2), 33-37.

Rodriguez-Rodriguez, S.E., Solis-Catalan, K.P., \& Valdez-Mondragon, A. (2015). Diversity and seasonal abundance of antrhripogenic spiders (Arachnid: Araneae) in different urban zones of the city of Chilpancingo, Guerrero, Mexico. Revista Mexicana de Biodiversidad., http://dx.doi.org/10.1016/j.rmb.2015.09.0 $\underline{02}$.

Seyfulina, R. R., G. N. Azarkina and V. M. Kartsev. (2020). A contribution to the knowledge of jumping spiders from Thailand (Aranei: Salticidae). Arthropoda Selecta, 29 (1): 87-96. doi: 10.15298/arthsel. 29.1.07

Weterings, R. and C. Umponstira (2014). Predation on Mosquitoes by Common Southeast Asian House-dwelling Jumping Spiders (Salticidae). Arachnology, 16(4), 122-133

World Spider Catalog. Natural History Museum Bern, tersedia secara daring: http://wsc.nmbe.ch, version 17.0 (diakses tanggal 11 Mei 2021).

Zabka, M and J. Gardzinska (2017). Salticidae of Thailand. Part 1, genera plexippus C. L. Koch, 1846 and burmattus Prószyński, 1992. Annales Zoologici, 67(2), 229-242. doi:

10.3161/00034541ANZ2017.67.2.004

Zabka, M. (1985). Systematic and zoogeographic study on the family Salticidae (Araneae) from Viet-Nam. Annales Zoologici, 31(12), 197-485.

Zabka, M. and W. Nentwig (2000). Salticidae (Arachnida: Araneae) of the Krakatau Islands (Indonesia). A preliminary approach. Ekológia (Bratislava), 19(3), 293-306. 